\title{
North Aegean island landscapes as ecomuseums: the case of Lesvos Island
}

\author{
Evangelos Pavlis \\ Panteion University of Social and Political Sciences, Athens, Greece \\ evan.pavlis@gmail.com
}

The main advantage of the Aegean islands, in generating national, regional, or international competitiveness, compared to the areas on the continental mainland, is their natural and cultural assets, their cultural landscapes. Consequently, the organized utilization of cultural heritage, rich biodiversity, and the unique Aegean landscape, could make the islands attractive as places to live or work and help them fulfill their sustainability goals. Ecomuseums are 'in situ' museums, aimed at local communities and managed by them, aiming at the interpretation, protection, utilization, and promotion of natural and cultural assets of a place, and at the economic revival of marginal regions through the combinational development of small-scale tourism, local manufacturing, and primary production sectors. They could function as laboratories of sustainable development. The island of Lesvos has been selected as a case study for such a potential ecomuseum.

Keywords: community, cultural landscape, ecomuseum, sustainable development

https://doi.org/10.24043/isj.9

(C) 2017 - Institute of Island Studies, University of Prince Edward Island, Canada.

\section{Introduction}

The globalized economy of regional and sectorial inequalities and the productivist model of intensive output often lead places of physical, demographical, technological, and economic disadvantages into marginalization. Such marginalization is often observed in rural and insular areas. The islands of the North Aegean face serious challenges, such as problems in accessibility, transport costs and lack of economies of scale, low productivity, low added value, demographic problems, a high percentage of long-term unemployment, seasonal employment of non-qualified personnel, low percentages of competitiveness and innovation, migration, and illegal migration (ESPON, 2010). As a result, they cannot achieve the reduction of production costs, so as to establish competitive economic activities and meet their goals for sustainable development and economic, social, and territorial cohesion. Thus, such societies should either attempt a) to find new ways to overcome their disadvantages based on their predominant development model, or b) adopt a new sustainable development model.

The improvement of their attractiveness could be derived from a combinational utilization of their natural and cultural assets (production, manufacture, cultural heritage, biodiversity, etc.), along with an organized activation of their human capital, through a strategic investment in quality, locality, and innovation (ESPON, 2010). In this respect, landscape could be the context, the reference point, and the geographical unit of analysis through which the social, natural, spatial, cultural, and human capital could be identified, assessed, and activated, in order for sustainable development to be achieved. The aim of this paper is a) to link the concept of landscape as a cultural product and as 
a sustainable resource to the concept of 'ecomuseum' as an item of research and as a participatory strategy/tool for sustainable development, and b) to approach and assess the different but interrelated and interdependent dimensions of the cultural landscape of a lagging island, pointing to the need to improve the landscape quality and to activate its resources and assets in order to fulfill sustainability goals by organizing (part of) the landscape as an ecomuseum. The island of Lesvos in Greece, affected by a multifaceted crisis (financial, economic, migrant, etc.), has been selected as a case study.

\section{Cultural landscape as a sustainable resource}

According to the European Landscape Convention (ELC, Florence, 2000) landscape is "an area, as perceived by people, whose character is the result of the action and interaction of natural and/or human factors" (ELC, article 1a, 2000). A landscape is the perceptual, emotional, and ideological picture of a place (Stefanou, 1980; Duncan \& Ley, 1993) experienced by the entirety of the human senses. It is a tangible, readily perceived geographical unit of analysis, through which human-space interrelationships evolve and materialize, take shape and expression, are experienced and conceived. The landscape is produced and reproduced through the human senses, cognitive and mental processes, emotions, practices and behaviours, and the analysis of their relations and interactions with space, and can holistically impress the people-space relationship (Terkenli \& Pavlis, 2012); either expressed on the earth's surface, or on a television screen and in virtual reality, in literary form, in music, on canvas, in various smells, tastes, and sounds. Landscapes are cultural images that "reveal, represent and symbolize the relationships of power and control out of which they have emerged and the human processes that have transformed and continue to transform them [...] hiding the processes that have made them-social, political, economic, spiritual-behind a placid and familiar surface" (Robertson \& Richards, 2003, p. 4). They are the expression of the deeper meaning of a place, helping its physiognomy to be conceived (Stefanou \& Stefanou, 2005). Physiognomy concerns "the uniqueness, the identity, or even the personality of a place, as it is being formulated and appeared in the characteristics of its landscape" (Stefanou \& Stefanou, 2005, p. 4).

Following the humanist tradition of the 1970s (Buttimer, 1976; Seamon, 1979), landscape was perceived as embracing the subjective, cultural, ideological, and ethical aspects of the spatial experience. During the 1980s, landscape was understood not only as an image but also as a 'way of seeing', delving into aspects of 'high' and 'popular' culture, social practices, control and power relations in the claim of space (structuralist tradition) (Terkenli, 1996; Meinig, 1979; Mitchell, 2000). By the end of the decade, the landscape was perceived as "a cultural image, a pictorial way of representing or symbolising surroundings" and as a context of multidimensional and dynamic social and cultural phenomena (Cosgrove \& Daniels, 1988, p. 1) and as a text (Duncan \& Duncan, 1988). During the 1990s, there was a transition from 'structures' to 'relations' and the landscape comprised an integrated way of approaching human-space relationships, susceptible to various interpretations (Harvey 1989; Featherstone, 1991; Soja, 1996; 2001; Rose, 2003). A move away from the approaches of landscape as an image, as a context, and as a text (although they continue to be important) towards an understanding of landscape "as part of a process by which [...] identities are formed" (Mitchell, 1994, p. 11), as a product of a dynamic cultural process which is always in a constant way of becoming, a work in progress (Ingold, 1993). "Landscape does not simply mirror or distort 'underlying' social relations, but needs to be understood as enmeshed within the processes which shape how the world is organized, experienced 
and understood, rather than read as its end product" (Seymour, 2000, p. 214). Jorgensen (1997) suggests that landscape does not contain only our experience of the physical environment but also stories, symbols, myths [and] images...[while] analyzing a landscape, we analyze ourselves, where "everything is connected in a continuous network of meaning" (Jorgensen, 1997, p. 42). Thus, landscape was assumed both as a material space but also as a representation, both as 'sign' and as 'signified', both as frame/representation and as substance, both as package and its product (Hadjimichalis et al., 2012; p. 235; Mitchell, 1994), paving the way to the onset of 'more-thanrepresentational geography'. During the 2000s, more-than-representational geography signaled another transition from representation in theory to the experience through the human body (e.g., experience through trekking, driving, bicycling, climbing, gardening) and from the dominance of the visual to the significance of the entirety of the senses through which the landscape is experienced (Thrift, 1996; Lorimer, 2005; 2007; Wylie, 2007; Dewsbury et al., 2002). The human subjects are perceived "not as spectators, but also participants, in the very performance of their tasks" (Ingold, qtd. in Wylie, 2007, p. 160). The more-than-representational theory focuses on "how life takes shape and gains expression in shared experiences, everyday routines, fleeting encounters, embodied movements, precognitive triggers, practical skills, affective intensities, enduring urges, unexceptional interactions and sensuous dispositions" (Lorimer, 2005, p. 84); also as regards place and landscape, perception and interpretation. In contemporary cultural geography, landscape is described as "the mutual embeddedness and interconnectivity of self, body, knowledge and land" (Wylie, 2007, p. 1). The basic assumption is that if humans think with their bodies, they have to think, act, associate and interact with the landscape through their bodies (Wylie, 2007). As Wylie (2007) suggests, the meaning of landscape shifts from 'landscape-asimage' to 'landscape-as-dwelling' and 'being-in-the world' (Ingold, 2000), which is "a substantive shift from horizon to earth', including "shaping of self, body and landscape via practice and performance' [...] such as "walking, looking, driving, cycling, climbing and gardening" (Wylie, 2007, p. 166), which may be understood as "embodied acts of landscaping" (Lorimer 2005, p. 85).

The European Landscape Convention aims at "achieving sustainable development based on a balanced and harmonious relationship between social needs, economic activity and the environment", improving human quality of life through the landscape, public participation in its protection, management and planning, along with the organization of European co-operation and synergy in landscape matters. The quality and the variety of landscapes constitute a common resource "favourable to economic activity and whose protection, management and planning can contribute to job creation" (ELC, Preamble). Each Party signing the Convention undertakes "to increase awareness among the civil society, private organizations, and public authorities of the value of landscapes, their role and changes to them" and "to define landscape quality objectives for the landscapes identified and assessed, after public consultation" (ELC, article 6). The achievement of those tasks is meant to be attained through awareness-raising, and the education and training of the civil society, private organizations, and public authorities in landscape matters.

Landscape studies deal with the multidimensional tourism-landscape relationship through lived and interactive experiences, perspectives, expectations, and desires (Lorimer, 2005), placing an emphasis not only on imagery and on the notion of tourist gaze, but also on 'sensescapes' and multisensual sensitivity, embodiment, and expressive practice (Terkenli, 2014; della Dora, 2009). Tourism geography addresses the relationship among place, landscape, and tourism. Agricultural, ecological, ethnographical, folklore, historical, 
and archaeological (living) heritage which is promoted by the tourism industry is expressed, represented, sensed, and experienced throughout the landscape. The landscape, along with specific assets, constitute a common good, a source of identity, heritage, and a valuable sustainable resource, entailing rights and responsibilities for everyone.

\section{The ecomuseum as a territorial asset}

The ecomuseum concept was introduced by museologists Hugues de Varine and Georges H. Riviere in 1971. The word 'ecomuseum' originates from the Greek words 'ecos', meaning the 'natural environment', and 'museum', meaning a place or temple dedicated to the 9 Muses of the Greek Mythology (goddesses of the various arts). Interestingly, the Muses were primarily the goddesses of the mountains and lakes. An ecomuseum is a museum of culture, nature, and history without walls; spread over a geographical area (Davis, 2011; Karp et al., 1992); promoting society-landscape relations (Babic, 2009; Zapletal; 2012); associating the 'exhibits' to the forms, functions, and values of the wider natural and human environment; and creating an awareness of history in a territory, by those creating history: the communities. An ecomuseum is a community-oriented museum that involves a multi-level approach, from local to global and vice versa, resisting the trends towards commercialization and commodification of the commons (Bigell, 2012; Zizek, 2009; Hess, 2008).

Ecomuseums focus on the identification, analysis, and processing of humanplace/landscape interrelations and on the interpretation of cultural landscape, emphasizing their interconnectedness and offering the background for an integrated tourism policy (Davis, 2011). An ecomuseum impacts on the protection, management, and planning of the cultural landscape (Zapletal, 2012; Maggi, 2002), and particularly on the combination of geological, morphological, ecological, socio-economic, ethnographic, historical, archaeological, aesthetic, mythological, symbolic, and other tangible and intangible elements and characteristics of a place. Ecomuseums have the potential to develop local economies through the promotion of ecotourism and cultural tourism (since tourism becomes increasingly specialized). Such types of tourism can provide a variety of resources that cannot be holistically and jointly provided by other museums: heritage attractions, religious sites, festivals and events, commerce, arts and crafts, sports and leisure, food and drink, language insights, special education, walking routes, living experience, etc. They also have the potential to offer the background for an integrated rural policy based on commons (e.g., based on 'Participatory Guarantee Systems', Vandecandelaere et al., 2010). Ecomuseums focus on the integration of tangible and intangible commons in a specified territory, and on the integration of various local actors and networks and of different administrative levels (local communities, local authorities, government structures, local businesses, academic advisers, NGOs, cultural and environmental unions and societies, etc.).

In general, ecomuseums constitute a holistic approach to culture-nature, peoplelandscape, local-global, tangible-intangible, agriculture-nutrition, consumers-producers, and past-present relationships, appearing as a new tool for local development through the utilization of local natural, cultural, human, spatial, and social capital. These are the main interesting points that differentiate ecomuseums from traditional top-downoriented museums and from other bottom-up-oriented museums, such as geoparks, that are not able to capture the special nature and the physiognomy of places (Davis, 2011). Local communities maintain the control and management of their ecomuseums, on the basis of a social contract, entailing the keeping of ethical commitments to society and community and including continuous public consultation towards the fulfilment of a 
vision of sustainable local development (de Varine, 1996; Maggi, 2002; Massey, 2014). The ecomuseum is a "social contract for a common future" (Gousios, 2013, p. 82; Raffestin, 1986; Calame, 2012). Interestingly, nearly half of the ecomuseums in the world are spread across European Mediterranean countries: Italy, Spain, Portugal, and southern France. Their sources of income are EU programs, projects, admission fees, shop sales, funding from organizations, clusters, school fieldtrips, etc.

According to the above, the main scopes of an ecomuseum are: a) the preservation of the commons of a place (i.e., the natural and cultural heritage, consisting of tangible and intangible elements), b) the empowerment of the local economy through the new prospects of sustainable development, and c) local governance, the strengthening of the 'sense of community', and the improvement of quality of life. In terms of the first scope, the basic aims of an ecomuseum appear to be the sustainable management of the 'commons' of a place, preserving them from destruction/disappearance or from deterioration (i.e., their generification by the massive industry and specifically by the touristic and the agri-food industries, since ecomuseums promote alternative sources of tourism and responsible tourism, local production, direct marketing schemes, etc.), or by their privatization (through their utilization by private companies and not by public/ collective structures). Today, the common natural and cultural resources have become an item of expropriation by the tourism and food industries, during the process of identification of origin-linked products. Such uncontrolled exploitation of local resources through the superficial expropriation and underutilization of human, cultural, natural, spatial, and social resources, without the "bottom-up" participation of local society, could mortgage the future of territorial development and increase its social exclusion (Gousios, 2013; Pérez, 2010). In terms of the second scope, the basic aims appear to be the encouragement of local communities to develop their cultural services and facilities, the promotion of local production and cuisine, the rejuvenation and support of a variety of arts and crafts and traditional professions (such as stonemasons, tailors, needleworkers, soapmakers, carpenters, charcoal makers, packsaddlers, tinkers, basket makers, cutlers, etc.), the recording and communication of historical memory, the modernized revival (or re-invention) of local ethics, customs, traditions and celebrations, the development of new products, services, and ideas, and the promotion of alternative sources of tourism (such as agro-tourism, ecotourism, cultural, gastronomic, and science tourism, etc.). The attractiveness and the economic viability of an area are improved when the community takes advantage of the relations, bonds, values, and practices, as articulated in space, by transforming them into assets that empower its territorial hypostasis and the common sense of belonging of its members, evoking myths of quality and identity. As a destination it is aimed at various tourist/visitor groups of special interests, schools and academic institutions, researchers, etc. Thus, the ecomuseum could constitute the terroir through which specialized products and services, which encapture the local heritage, the biodiversity, and the landscape physiognomy, are produced (e.g., basket of complex territorialized goods, Anthopoulou, 2013; Hirczak et al., 2008; Pecqueur, 2001). In terms of the latter scope, the main aims are configured as follows: local activation and empowerment of 'civil society'; management and planning "by the local community for the local community" (bottom-up approach, i.e., local people decide what aspects of their 'place' are important to them and address the values attached to landscapes); the development of an environmental/landscape conscience and the empowerment of the sense of identity; and the co-operation among local actors, administrative bodies, scientists, NGOs, and citizens, based on a social contract with shared responsibilities, decided after general stakeholders' meetings. An ecomuseum is a 'community museum' (de Varine, 1996) involving bottom-up management and development through the active participation 
of the civil society (Heritage Saskatchewan, 2016), which identifies the value of resources and attempts to turn them into valuable assets. The utilization of local and regional knowledge and heritage is guided by a spatial vision of a common desirable future. Roe (2012) suggests that in many cases the common desire to conserve the landscape is not simply a matter of aesthetics, but regards the perception that the landscape encompasses a series of social, economic, and cultural values requiring many years to be constructed and the sense that landscape qualities, such as character, identity, and heritage, should be preserved. Pugh (2013), in his study in Barbados, detects the feelings of alienation and limitations of expression in participatory planning, derived from the inability of the fisherfolk to construct a collective narration (i.e., develop their own voice) and a unified vision for Barbados. A project was initiated aiming to examine what prevented them from developing a voice. The researcher emphasizes the need to consider fishing as 'a way of life', for fishers-and not academics or civil servants- to become their own development consultants (trusted and paid for consultation), to develop their own regional networks, acquiring more control over their industry, and to adopt a "new participatory planning ethos [...] into a concern with latent subjectivity and realization of the self" (Pugh 2013, p. 1278). Such issues should be central to the establishment of any ecomuseum.

At this point, it is important to explain the process of transformation of a resource into an asset, since this could be one of the significant functions of an ecomuseum. A placespecific natural or cultural resource develops into an asset by undergoing a process of 'metamorphosis', meaning the changing of its nature. The (re)building of the assets of a place requires collective ability for their conversion from "generic" to "specific" (Colletis \& Pecqueur, 1995; Pecqueur, 2013). Generic assets exist in many different places, they are transferable, and they can be produced by any private company of the globalized market. Whereas specific assets are the collective product of the interactive processes in a society, constructed by actors of different skills that produce new knowledge, they do not exist independently of the conditions under which they have been constructed and they cannot be transferred to 'others' (Pecqueur, 2013; Ostrom, 1990). Generic assets, which could turn into specific, could be a) food and drink products made of traditional recipes, b) indigenous varieties of plants and breeds of animal, c) products made of renewable biological resources (bioproducts), d) local arts and crafts, e) local festivals, celebrations, and farmers' markets (selling of farm-origin and predominantly fresh fruits, vegetables, meats, fish, beverages, etc., directly to consumers), f) services such as routes in breweries, wineries, cideries, and distilleries, g) services such as trekking, bicycling, jeep safaris, horse riding, etc., and new ways of experiencing the landscape, $h$ ) services of alternative sources of tourism, such as ecotourism, agrotourism, diving tourism, wild nature tourism, therapeutic and spa tourism, birdwatching, etc. The above assets could be combined so as to offer an integrated experience of people, places, and products, by originating both from the present and the past, shaping the character, identity, and hypostasis of a territorial entity and creating a critical mass for sustainable development (Vandecandelaere et al., 2010). The process of 'specification' concerns the qualification and differentiation of resources by the producers in accordance with consumer trends and also the attribution of new uses and values. It does not only include the conditions of soil and climate, but also the techniques and practices of the processing of primary resources and the federal reserve passing from generation to generation (which is often a long process of accumulation of know-how and is assumed as a significant part of collective heritage; Pecqueur, 2013), the environmental factors, the local social and cultural conditions, the linkages of people, places, and products in terms of identity, history, and culture, through which the innovation of a product/service is promoted (Belletti \& Marescotti, 2013). Specific assets constitute a powerful, unique, and nonproducible relation with the place of origin (Belletti \& Marescotti, 2013, p. 127), aka a 
product of a specific collectivity, in a specific time and space, produced under special circumstances, processes, and synergies, and there lies their unique value and their competitive advantage (Gousios, 2013; Torre et al., 2006; Joffre \& Koenig, 1992). However, until today, generic assets have rarely been transformed into specialized assets, and ecomuseums can contribute towards that direction.

\section{The case study of the landscape of Lesvos as a territorial ecomuseum}

Nowadays, the insular communities of the North Aegean have a restricted social capital (e.g., cultural societies/unions), since many past forms of social economy (e.g., co-operatives) have been dissolved or under-function, but they also have a high potential for the utilization of common goods and territorial assets and many diaspora networks that maintain strong relations with their places of origin. Most of their performances (GDP/capita) are lower than the national ones, below the European average, and, in fact, the poorest in the EU. The biggest islands of the North Aegean (Chios, Lesvos, and Samos), have been categorized as "lagging islands" and characterized as the least attractive, with a low performing economy, negatively influencing all the examined parameters (ESPON, 2010). Thus, there is an urgent need for organization and co-ordination towards common goals (Gousios, 2013; Anthopoulou, 2013). As it has been described, the cultural landscape could be the geographical unit of analysis and the multidimensional territorial resource through which the social, natural, spatial, cultural, and human capital, including the geographically indicated generic resources and assets, could be identified, analyzed, assessed, and activated, in order for sustainable development to be achieved. In other words, the cultural landscape could become a territorial ecomuseum.

\subsection{The landscape of Lesvos: an introduction}

The island of Lesvos is situated in the north-eastern Aegean Sea and has an area of 1.632 $\mathrm{km}^{2}$ and a coastline of $370 \mathrm{~km}^{2}$; it is the third largest island of Greece and the seventh largest in the Mediterranean. The population of the island is 86,436 inhabitants (according to the 2011 Census). The multiform terrain of littoral/coastal, hilly areas and uplands, the tectonic character of the island and its geodiversity, the mild Mediterranean climate, the rich variety of ecosystems and ecological reserves, along with the continuous human impact on the environment since prehistoric times, shape the physical and human geography of the island: fossil and volcanic sites, hot springs, caves, waterfalls, a variety of species of flora and fauna, ancient, Byzantine and more recent 'traditional' or contemporary monuments, fishing harbours and coves, marine sports amenities, castles, churches and monasteries, a network of trails, swimming beaches, etc., are all significant parts of the cultural landscape of Lesvos. The local economy is based on agriculture, while a large proportion of the population also deals in wholesale and retail trade, construction, public administration, and tourism services. The following map (Figure 1) presents the natural sites of the island (geosites) in orange dots and the cultural sites in yellow dots. The island of Lesvos as a whole has been designated as a 'UNESCO Global Geopark' and is an international destination for birdwatchers and wildlife tourists, and in general ecotourists and geotourists.

The general distinct characteristics of the landscape of Lesvos are:

a. the remains of the dynamic volcanic activity of the past,

b. the local fauna and flora that include species of both the Orient and the West (due to the fragmentation and sinking of Aegiis in 10.000 BC, when Lesvos was part of Asia Minor),

c. the variety of ecosystems, birds, bees, and wildflowers, and

d. the rich cultural heritage. 
Figure 1: Natural and cultural sites of Lesvos Island.

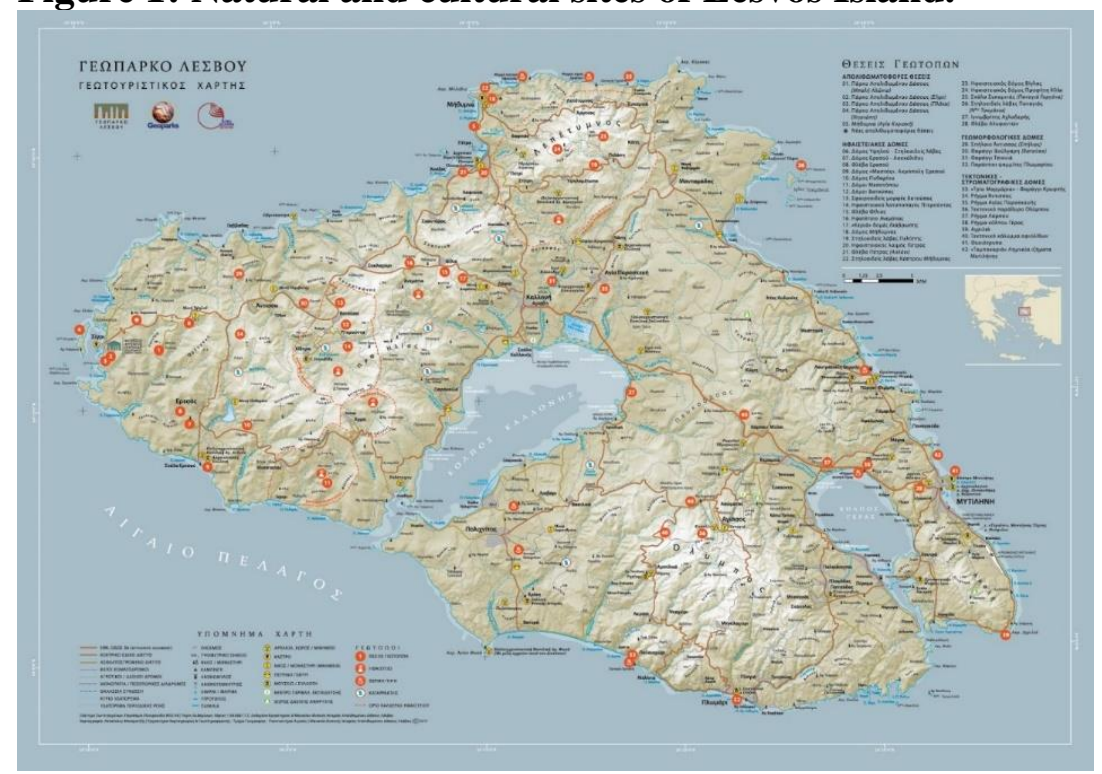

Source: Natural History Museum of the Lesvos Petrified Forest.

Landscapes are continuously changing. The main driving forces affecting the landscape change processes are internal and external. Among internal forces are changes at the national and regional or local level, whereas among external forces are changes at the European or international/global level. Such driving forces of change are often categorized as political, economic, cultural, technological, and environmental (Hersperger \& Burgi, 2009; Kristensen et al., 2009) and in the case of Lesvos, EU policy (environmental laws, Natura 2000, tourism development, agrotourism, agricultural subsidies, and other CAP programs, etc.) and spatial planning (lack of land planning, construction outside [the] town plan[ning], spread of second home ownership, etc.) seem to be the main forces of change, affecting the landscape in direct and indirect ways (Van der Sluis et al., 2015). Other forces, which are often the result of national/regional policies, are demography, cultural values, social services, transport, unsustainable use of natural resources, etc., but also more international forces, such as global market economy, urbanization, etc. In order to approach the territorial potential of natural and cultural resources, we have to describe, analyze, and evaluate the dimensions of the landscape of Lesvos.

\subsection{The dimensions of the landscape of Lesvos: Detecting the territorial potential (natural and cultural resources)}

The landscape of Lesvos entails many interrelated and interdependent dimensions, experienced through the entirety of the human senses:

a) natural dimensions (geology, geomorphology, climate)

b) functional-utilitarian-ecological dimensions,

c) socio-economic dimensions,

d) historical-archaeological dimensions

e) representational-aesthetic dimensions

f) symbolic dimensions, and

g) experiential-emotional dimensions.

All the above landscape dimensions include an entirety of potential resources and assets.

The natural (geological, geomorphological, and climatic) dimension of the landscape concerns the terrain and the territorial formations, along with the structure of geological characteristics, shaping the landscape and strongly impacting on its other 
dimensions. The geological potential of Lesvos is evident in different parts of the island in many volcanic plant and mammal fossil sites, tectonic sites, in caves and karstic structures, in waterfalls, in thermal springs, in ancient quarries, and other sites of scientific, educational, and aesthetic value meant for tourist, research, and educational use, and strongly constituting the landscape character of Lesvos. The mild Mediterranean climate with a mean annual temperature of $18^{\circ} \mathrm{C}$ and a mean annual rainfall of $750 \mathrm{~mm}$ makes it one of the sunniest Aegean islands. Lesvos is well known for its Petrified Forest covering an area of 15,000 ha, consisting of the remains of fossilized plants and, in fact, of an entire well-preserved autochthonous fossilized forest ecosystem that appears within the volcanic rocks. It is a landscape of great geological interest and scientific value, since it entails rich geohistorical evidence of the development of the Aegean over the past 20 million years. Besides the Petrified Forest Park, there are four similar newer parks. Major threats to this landscape dimension are the large infrastructure projects (e.g., fast-track investments), the lack of land-planning, and the construction outside (the) town plan(ning) that do not consider the landscape scale of the island.

The functional-utilitarian-ecological dimension regards the various ecosystems, their biodiversity, land uses, and management. In the eastern and central parts of the island, the landscape of Lesvos combines a variety of ecosystems such as olives, pine and oak forests, and grazing and arable land, and has (55\%) more rainfall than the western part. Olive plantation is the most characteristic local land use and ecosystem since 200-250 years ago (there are some ancient olive groves, too) and one of the most important elements of the character of the landscape of Lesvos. In the western part of the island, the landscape is hilly, characterized by intense volcanic activity and many fossil and tectonic sites. Western Lesvos is ideal for range uses (rangelands for sheep), thus there is limited horticulture (phytogenic coverage) and rainfall. The plurality of ecosystems offer habitat to a great variety of plant, bird, mammal, reptile, and amphibian species, some of them rare and protected. There are more than 200 bird species, 550 species of bees, 45 different species of dragonflies, 100 species of orchids, etc. There is also a wide variety of wildflowers, mushrooms, and aromatic and medicinal herbs (e.g., the landscape of Mount Olympus is of great botanical interest). One third of all Aegean wetlands can be found in Lesvos; there are 54 natural and 6 artificial wetlands. Construction outside the town plan, water, air and soil pollution, waste disposal, fires, landfills, artificial embankments, and illegal fishing and hunting constitute major threats to this landscape dimension.

In terms of its socio-economic dimension, agriculture and tourism comprise two significant pillars of the local economy that highly impact on the (re)production and consumption of the landscape. Agricultural production includes stock-breeding, fishing, and especially olive cultivation which has had a long history since antiquity and especially since 200-250 years ago when the largest part of the olive grove was planted. During the past two centuries the economy and everyday life have revolved around olive oil: family farming, team working, prescribed gender roles, co-operatives, processing in olive mills, terraces, fences, rural constructions, footpaths, picturesque country churches, the culture of olive celebrations and festivals, and local artisans working with olive wood, etc. Such characteristics have a significant impact on the island landscape which is today threatened by land abandonment (Van der Sluis et al., 2015). Tourism is mostly run by small family businesses and small hotels and supported by restaurants, taverns, and cafes. According to Spilanis (2016), despite the variety of natural and cultural resources, Lesvos is characterized by limited, seasonal (1-2 month tourist season) tourism activity of low income, insufficient infrastructure, and poor quality of services. There is an attachment to the 3Ses (sea, sand, sun) model of mass tourism and a growing number of all-inclusive hotel contracts. There is a low participation of tourism businesses in local quality agreements and environmental 
management plans. Today, despite the fact that serious ecosystem destruction has generally been prevented and the architectural character of the island has been preserved in many areas, there is a general failure to protect and utilize local development resources (production, arts and crafts, biodiversity, cultural heritage, landscape). Tourism and agricultural development are not based on a comprehensive action strategy and an integrated approach for a coherent agricultural policy, marketing of agricultural products, land planning, environmental conservation and management, utilization of natural and cultural resources, and branding of the island and community well-being.

The landscape is a rich historical record, a mosaic of different elements, evidence of historical evolution of a human society. It functions like a palimpsest (Bender, 1993; Crang, 1998; Muir, 1999; Rackham \& Moody, 2012). The historical-archaeological dimension of the landscape of Lesvos is evident in many archaeological sites, such as the areas of Ancient Antissa and Mithimna; the temples of Messa, Klopedi, and Chalinados; the remains of the Roman Aqueduct spread in many areas of the south-eastern part; the remnants of the Ancient Theatre of Mytilene with marvelous acoustics; the 'Lesvian style' well-built wall in Apothika Agras; the prehistoric settlement of Thermi; the Acropolis of Eresos; and the various ancient remains spread all over the island, etc. It is also evident in medieval castles and many scattered castle ruins; in Byzantine Monasteries with folklore museums and libraries; in old churches; in towers, mansions, and the neoclassical style 'archontika' that testify to ages of prosperity and grief; along with the different nature and practice of human-landscape relations and the different aspects and levels of landscape conscience. Such heritage has not been conserved during the past decades and today there is not always enough care for the preservation and management of ancient, Byzantine, and more recent monuments.

The representational-aesthetic dimension of the landscape (landscape as a view/scenery) is constructed in the mind of the observer. The foundations of the landscape-observer relationship are associated to the landscape character, to the landscape characteristics, and to the landscape scale. The landscape character is "a distinct and recognizable pattern of elements that occur consistently in a particular type of landscape. Particular combinations of geology, landform, soils, vegetation, land use, field patterns and human settlement create character. Character makes each part of the landscape distinct, and gives each its particular sense of place" (Swanwick, 2002, p. 9). Characteristics are the "elements, or combinations of elements, which make a particular contribution to distinctive character" (Swanwick, 2002, p. 8).

There are three main landscape character types in Lesvos shaping a common pattern:

a) The olive planted south-eastern part: the south-eastern landscape of highly productive land (pine trees and olive groves), damp climate, historical and archaeological heritage, wholesale and retail trade, fishing, public administration, some mass tourism, and urban expansion.

b) The volcanic western part: the hilly western part of arid land (grazelands), soil erosion, intense volcanic activity, historical and archaeological heritage, and some mass tourism.

c) The mixed central part: the central part of diverse land types and uses, historical and archaeological heritage, and mass tourism.

The appropriate scale is defined by the size, shape, position, etc., of the main characteristics of each landscape. The existence of scale abolishes the approach 'one size fits all' and determines the potential of interventions in an area. Today, the representational dimension of the landscape of Lesvos is threatened by large-scale investments (exceeding the local landscape scale) and by the lack of a land-use policy and plan based on significant local landscape characteristics that shape its landscape character 
(e.g., olive groves, grazelands, volcanic activity, fossils, hot springs, wetlands, birds, orchids, terraces, watermills, bridges, antiquities, footpaths, traditional villages, local architecture, small-scale tourism, co-operational culture, ouzo, and olive culture). The predominant characteristics of the landscape add aesthetic value to it, thus they should be preserved and well-managed. The attribution of aesthetic value is associated to the embodiment of landscape qualities (e.g., view, beauty, harmony, peacefulness, sacredness) and, thus, to the improvement of human quality of life through the humanlandscape relationship. The aesthetic factor impacts on the human psychism and plays a significant role in shaping landscape perception (Knudsen et al., 2008).

The symbolic dimension of the landscape entails the tangible material structures, but also the intangible social and cultural structures, processes, and values, where the selected landscape forms obtain peculiar and distinct meanings. This dimension can shape ideal notions of landscapes or imaginary landscapes. "Land becomes landscape and landscape a sacred place" (Park \& Coppack, 1994, p. 162). A sacred landscape becomes a place that instructs humans on the values of spirituality. The symbolic system of each landscape represents a significant part of the cultural identity and hypostasis of its people. In Lesvos there are many myths and legends originating in antiquity or the Byzantine era, such as the Orpheus tomb and his worship, the legend of king Makaras, the heroine Orietta di Lesbo who became a leader of the Lesbians against the Turks (an opera of Verdi), and many tales of nymphs, elves and vampires, etc. The island is the birthplace of famous people of art and literature, such as the poets Sappho and Alcaeus, the Peripatetic philosopher Theophrastus and 'father of botany' Pittacus who was one of the Seven Sages of Ancient Greece, the singer and guitar player Arion, the musician and founder of the guitar Terpandros, but also modern ones, such as the writer Stratis Mirivilis (1892-1969), the major folk painter Theophilos Hatzimichael (1870-1934), the painter Georgios Jakobides (1853-1932), the Nobel prize winner (in literature) Odysseus Elytis (1911-1996), etc. For example, a strong heritage of the island is the fact that in the 4th century BC the Greek philosopher Aristotle traveled to Lesvos, after an invitation by its scholar Theophrastus, and his research on the island led to the birth of the science of biology. As Armand Leroi, Professor of Evolutionary Developmental Biology at Imperial College in London and presenter of the BBC documentary 'The Lagoon: How Aristotle Invented Science', puts it in his homonymous book: Lesvos, and especially the Gulf of Kalloni, was for Aristotle what the Galapagos were for Darwin (Leroi, 2014). Landscapes as symbolic spaces of national history express and embody the sense of belonging, preserving memories that are associated with history and geography, through myths, legends, and traditions (Häyrynen, 1998; Sooväli et al., 2003; Schama, 1995; Olwig, 1993). Such rich and dynamic intangible landscape embodiment is underutilized by various sectors of the local economy (such as tourism and agriculture) and education. In other words, myths, legends, traditions, stories, etc., could be used for the conservation, promotion, management. and planning of the island landscape for educational and economic purposes.

The experiential-emotional dimension of the landscape involves haptic, acoustic, smell and taste experience of the landscape, and the "feeling of doing" in the attempt to "make sense" of our body geographies (Paterson, 2009) and "binding of bodies-withenvironment" (Thrift, 2004). Even the protection of the view and architectural heritage should consider the acoustic experiences of a place, so as not to cause any kind of annoyance or psychological encumberment (e.g., in Aeolian parks' construction, Tabassum-Abbasi et al., 2014). During the last decade, there has been a development of new rural activities in Lesvos, such as hiking, climbing, mountain biking, horse riding, jeep safaris, scuba diving, etc., in combination with more traditional ones, like 
hunting, fishing and various agricultural activities. In general, there is a trend toward rediscovering and re-experiencing the rural landscape in new ways (Terkenli \& Pavlis, 2012; Woods, 2005; della Dora \& Terkenli, 2012). The landscape quality of Lesvos is advanced by various aromas, tastes, sounds, and haptic experiences of the geological and geomorphological diversity (different forms, shapes, etc.), different functions (land uses, ecosystems, etc.), rich animal and plant diversity (birds, reptiles, orchids, mushrooms, wildflowers, the Environmental Information Center of Kalloni, etc.), and the cultural heritage of natural resources and cultural assets (traditional recipes, equipment, knowhow and skills, cafeneions, tavernas, traditional villages, agro-tourism festivals and celebrations for ouzo, the sardine, the chestnut and some other products, the network of 20 trails, academic summer schools, environmental education activities, etc.). Such landscape characteristics favour landscape experience, the rise of feelings/emotions and memories, and the development of place-bonds. On the contrary, environmental pollution, the lack of waste management and infrastructure (e.g., for organized tours into wetlands), the problems of the road network, natural disasters (fires, floods, etc.), rural depopulation and the abandonment of the countryside, and farming intensification (pesticides, parasiticides, etc.), which describe, more or less, the situation of the local landscape today, impact negatively on landscape quality and experience.

\section{Conclusion}

The decline of landscape quality presented above means the decline of human-landscape relations leading to the decline/deterioration of generic resources and assets. All the identified landscape dimensions and resources/assets could be activated and advanced by the function of landscape as an ecomuseum, since the purpose of an ecomuseum is the preservation of the commons of a place, the empowerment of the local economy and local governance, the strengthening of the 'sense of community', and the improvement of quality of life. The (cultural) landscape of Lesvos could be transformed into an ecomuseum through the preservation and management of cultural heritage, biodiversity and common resources, the specialization of territorial assets, the localized system of governance (bottom-up approach) involving the integration of different administrative levels and of various local actors and networks, and giving 'voice' to the members of a community for them to realize themselves, to become more self-sufficient and to take more control over their industry. Thus, such a holistic approach of the ecomuseum can function complementally to the already existing Geopark. An integrated policy based on the conservation, management, and planning of the landscape, on a shared vision for management of resources and assets of a given territory, and on an effective coordination among stakeholders, could fulfill sustainability goals towards a common desirable future. An ecomuseum is a lifespace, a place of dwelling and being in the world for the local community and could be a laboratory for building, activating, and promoting its specialized assets in the form of socio-cultural products and landscape services, and adding value to the island bibliography and research focusing on ecomuseums, so as to fulfill its sustainability goals, especially for less favoured areas, such as the lagging islands.

\section{References}

Anthopoulou, T. (2013). Geographical indications and development dynamics in Greece. The hard emergence of collective action. In T. Anthopoulou (Eds.) On locality and particularity of foodstuffs: a territorial approach on rural development (pp. 255279). Athens: Papazisi editions (in Greek). 
Babic, D. (2009). Experiences and (hidden) values of Ecomuseums. Ethnological Researches, 14, 237-252.

Belletti, G. \& Marescotti, A. (2013) Typical agri-food products, local assets and sustainable development. In T. Anthopoulou (Eds.) On locality and particularity of foodstuffs: a territorial approach on rural development (pp. 121-141). Athens: Papazisi editions (in Greek).

Bender, B. (1993). Landscape: Politics and Perspectives. Oxford: Berg.

Bigell, W. (2012). Ecomuseum and the new commons. In S. Lira, R. Amoêda, C. Pinheiro, P. Davis, M. Stefano \& G. Corsane (Eds.) Ecomuseums 2012: Proceedings of the 1st International Conference on Ecomuseums, Community Museums and Living Communities (pp. 19-28). Green Lines Institute for sustainable development.

Buttimer, A. (1976). Exploring the dynamics of lifeworld. Annals of the Association of American Geographers 66(2), 277-292. https://doi.org/10.1111/j.14678306.1976.tb01090.x

Calame, P. (2012). Sauvons la democratie. Paris: Edition Charles Leopolf Mayer.

Colletis, G. and Pecqueur, B. (1995). Politiques technologiques locales et création de ressources spécifiques. In A. Rallet and A. Torre (Eds.) Économie industrielle et économie spatiale (pp. 445-463). Paris: Economica.

Cosgrove, D., \& Daniels, S. (1988). The iconography of landscape: essays on the symbolic representation, design and use of past environments. Cambridge, UK: Cambridge University Press.

Crang, M. (1998). Cultural Geography. London: Routledge.

Davis, P. (2011). Ecomuseums: a Sense of Place (2nd Edition). New York: Continuum.

della Dora, V. (2009). Travelling landscape-objects. Progress in Human Geography, 33(3), 334-354. https://doi.org/10.1177/0309132508096348

della Dora, V. and Terkenli, T. (2012). Cultural Geographies. In I. Vogiatzakis, (Eds.) Mediterranean Mountain Environments (pp. 137 - 157). Oxford: Wiley-Blackwell. https://doi.org/10.1002/9781119941156.ch7

de Varine, H. (1996). Ecomuseum or community museum? 25 years of applied research in museology and development. Nordisk museology, 2, 21-26.

Dewsbury, J.D., Harrison, P., Rose, M. and Wylie, J. (2002). Enacting geographies. Geoforum, 33, 437-440. https://doi.org/10.1016/S0016-7185(02)00029-5

Duncan, J.S., \& Ley, D. (1993). Place/Culture/Representation. London \& New York: Routledge.

Duncan, J. and Duncan, N. 1988. (Re)reading the landscape, Environment and Planning D: Society and Space, 6, 117-126. https://doi.org/10.1068/d060117

ESPON (2010). Islands' Atlas, The Development of the Islands - European Islands and Cohesion Policy (EUROISLANDS), ESPON 2013, Program ESPON \& University of the Aegean, Retrieved from:

https://www.espon.eu/export/sites/default/Documents/Projects/TargetedAnalyses/ EUROISLANDS/english Atlas.pdf.

Featherstone, M. (1991). Consumer Culture and Postmodernism. London: Sage.

Gousios, D. (2013). A territorial approach of rural development. In T. Anthopoulou (Eds.) On locality and particularity of foodstuffs: a territorial approach on rural development (pp. 72-105). Athens: Papazisi editions (in Greek).

Hadjimichalis, C, Melissourgos, Y, Moungolia, A., Girti, D., \& Faka, A. (2012). Improving and focusing research on Greek landscapes: the Greekscapes programme. In T. Papayannis \& P. Howard (Eds.) Reclaiming the Greek landscape (pp. 233-244). Athens: Med-INA.

Harvey, D. (1989). The Condition of Postmodernity. Oxford: Blackwell. 
Häyrynen, M. (1998). Isänmaan äidinkasvot. The images of fatherland. In M. Luostarinen \& A. Yli-Viikari (Eds.) Maaseudun kulttuurimaisemat. Rural landscapes in Finland (pp. 30-34). Helsinki: Finnish Environment Institute.

Heritage Saskatchewan (2016). Newly-forming ecomuseums development framework, Saskatchewan Ecomuseums Initiative (SEI) Steering Committee. Retrieved from: https://heritagesask.ca/pub/documents/Ecomuseums/Ecomuseums\%20Dev'1\%20Framework\%20(05\%202016).pdf.

Hersperger A.M., \& Burgi, M. (2009). Going beyond landscape change description: Quantifying the importance of driving forces of landscape change in a Central Europe case study. Land Use Policy, 26(3), 640-648. https://doi.org/10.1016/j.landusepol.2008.08.015

Hess, C. (2008). Mapping the new commons. Syracuse: Syracuse University http://surface.syr.edu/cgi/viewcontent.cgi?article $=1023 \&$ context=sul.

Hirczak, M., Pecqueur, B., Moalla, M., Mollard, A., Rambolinaza, T., Vollet, D. (2008). From the Basket of Goods to a More General Model of Territorialized Complex Goods: Concepts, Analysis Grid and Questions. Canadian Journal of Regional Science, 31(2), 241-259.

Ingold, T. (1993). Technology, language, intelligence: a reconsideration of basic concepts. In K. R. Gibson \& T. Ingold (Eds.) Tools, Language and Cognition in Human Evolution (pp. 449-72). Cambridge: Cambridge University Press.

Ingold, T. (2000). The Perception of the Environment: Essays on Livelihood, Dwelling and Skill. London: Routledge. https://doi.org/10.4324/9780203466025

Joffre, P., \& Kœnig, G. (1992). Gestion Stratégique. L'entreprise, ses partenaires adversaires et leur univers. Paris: Litec.

Jorgensen, S.E. (1997). Integration of Ecosystem Theories: A Pattern. Dordrecht: Kluwer Academic Publishers. https://doi.org/10.1007/978-94-011-5748-3

Karp, I., Kreamer, C., \& Lavine, S. (1992). Museum and Communities: The politics of public culture. Washington: Smithsonian Institution.

Knudsen, D.C., Greer, C.E., Metro-Roland, M.M., Soper, A. K, \& Greer, C.E. (2008). Landscape, Tourism, and Meaning. Aldershot, Hampshire, UK: Ashgate.

Kristensen S.B., Reenberg A., \& Pena J.J. (2009). Exploring local rural landscape changes in Denmark: A human-environmental timeline perspective. Geografisk TidsskriftDanish Journal of Geography, 109(1), 47-67. https://doi.org/10.1080/00167223.2009.10649595

Leroi, A.M. (2014). The Lagoon: How Aristotle Invented Science. London: Bloomsbury.

Lorimer, J. (2005). Cultural geography: the busyness of being 'more-thanrepresentational', Progress in Human Geography, 29, 83-94. https://doi.org/10.1191/0309132505ph531pr

Lorimer, J. (2007). Cultural geography: wordly shapes, differently arranged. Progress in Human Geography, 31, 89-100. https://doi.org/10.1177/0309132507073540

Maggi, M. (2002). Ecomuseums: European Guide. Allemandi.

Massey, S. (2014). We Need to Talk: Living Heritage, Ecomuseums and Community Development. Heritage Saskatchewan Research. Retrieved from https://heritagesask.ca/pub/documents/living-heritage/Part\%200ne\%20$\%$ 20Ecomuseums.pdf.

Meinig, D.W. (1979). The Interpretation of Ordinary Landscapes. New York: Oxford University Press.

Mitchell, D. (1994). Landscape and surplus value: the making of the ordinary in Brentwood, CA, Environment and Planning D: Society and Space, 12, 7-30. https://doi.org/10.1068/d120007 
Mitchell, D. (2000). Cultural Geography-A Critical Introduction. Oxford: Blackwell.

Muir, R. (1999). Approaches to Landscape. Houndmills: Macmillan. https://doi.org/10.1007/978-1-349-27243-3

Olwig, K.R. (1993). Sexual cosmology: nation and landscape at the conceptual interstices of nature and culture: or, what does landscape really mean? In B. Bender (Eds.) Landscape: politics and perspectives (pp. 307-343). Oxford: Berg.

Ostrom, E. (1990). Governing the Commons: The Evolution of Institutions for Collective Action. Cambridge, UK: Cambridge University Press. https://doi.org/10.1017/CBO9780511807763

Park, C. \& Coppack, P.M. (1994). The role of rural sentiment and vernacular landscapes in contriving sense of place in the city's countryside. Geografiska Annaler, 76B(3), 161-172. https://doi.org/10.2307/490639

Paterson, M. (2009). Haptic geographies: ethnography, haptic knowledges and sensuous dispositions. Progress in Human Geography, 33(6), 766-788. https://doi.org/10.1177/0309132509103155

Pecqueur, B. (2013). Territorial development. A new approach to development processes for the economies of the developing countries, Interthesis 10(2), 8-32. https://doi.org/10.5007/1807-1384.2013v10n2p8

Pecqueur B. (2001). Qualité et développement territorial: l'hypothèse du panier de biens et de services territorialisés. Économie rurale, 261,37-49. https://doi.org/10.3406/ecoru.2001.5217

Pérez, R. (2010). Sur la contingence des modes de gouvernance de l'action collective entendue dans ses complexités: Elinor Ostrom. Interlettre MCX-APC, 53, Juillet.

Pugh, J. (2013). Speaking without voice: participatory planning, acknowledgment, and latent subjectivity in Barbados. Annals of the Association of American Geographers, 103(5), 1266-1281. https://doi.org/10.1080/00045608.2012.706571

Rackham, O. and J. Moody. (2012). Drivers of Change and the Landscape History of 'Cavo Sidero", in T. Papayannis and P. Howard (Eds.) Reclaiming the Greek Landscape (p. 219-232). Athens: MEDINA.

Raffestin, C. (1986). Territorialite: Concept ou Paradigme de la geographie sociale? Geographica Helvetica, 2, 91-96. https://doi.org/10.5194/gh-41-91-1986

Robertson, I. and Richards, P. (2003). Introduction. In I. Robertson \& P. Richards (Eds.) Studying Cultural Landscapes, London: Arnold.

Rose, G. (2003). Family photographs and domestic spacings: a case study. Transactions of the Institute of British Geographers, 28, pp. 5-18. https://doi.org/10.1111/1475$\underline{5661.00074}$

Roe, M. (2012). Public participation and governance in landscape decisions. In T. Papayannis, P. Howard (Eds.) Reclaiming the Greek landscape (pp. 255-270). Athens: Med-INA.

Schama, S. (1995). Landscape and Memory. London: Harper Collins.

Seamon, D. (1979). A Geography of the Lifeworld: Movement, Rest, and Encounter. NY: St. Martin's.

Seymour, S. (2000). Historical geographies of landscape. In B. Graham and C. Nash (Eds.) Modern historical geographies. Harlow: Prentice Hall.

Soja, E.W. (1996) Thirdspace: journeys to Los Angeles and other real-and-imagined places. Cambridge: Blackwell.

Soja, E. (2001) Postmodern Geographies. The Reassertion of Space in Critical Social Theory. London: Verso.

Sooväli, H., Palang, H., Külvik, M. (2003). The role of rural landscapes in shaping Estonian national identity. In T. Unwin and T. Spek (Eds.) European Landscapes: From 
Mountain to Sea. Proceedings of the 19th session of the Permanent European Conference for the Study of the Rural Landscape at London and Aberystwyth (pp. 114-121). Huma: Tallinn.

Spilanis, I. (2016). The case of South and North Aegean, Report for the Aegean Observatory for Sustainable Tourism, University of the Aegean (in Greek).

Stefanou, J. (1980). Etudes des paysages-vers une Iconologie de l'image (Doctorat d' Etat), Strasbourg: Univ. de Strasbourg I (in French).

Stefanou, I. and Stefanou, I. (2005). The physiognomy of the Hellenic city. In P. Doukellis (Eds.) The Hellenic landscape. Studies of historical geography and landscape perception (pp. 237-252). Athens: Estia (in Greek).

Swanwick, C. (2002). Landscape Character Assessment Guidance for England and Scottish. Cheltenham and Edinburg: Countryside Agency and Natural Heritage.

Tabassum, A., Premalatha, M., Abbasi, T., Abbasi, S.A. (2014). Wind energy: Increasing deployment, rising environmental concerns. Renewable and Sustainable Energy Reviews, 31, pp. 270-288. https://doi.org/10.1016/j.rser.2013.11.019

Terkenli, T.S. (2014). Landscapes of tourism (pp. 282-293). In A. A. Lew, C. M. Hall, and A. M. Williams (Eds.) The Wiley Blackwell Companion to Tourism. Chichester: John Wiley \& Sons. https://doi.org/10.1002/9781118474648.ch22

Terkenli, T. S. (1996). The cultural landscape: geographical approaches. Athens: Papazisis Publications (in Greek).

Terkenli, T. S. and Pavlis, E. (2012). Landscape conscience: awareness raising, training and education. In T. Papayannis and P. Howard (Eds.) Reclaiming the Greek Landscape (pp. 245-254). Athens: Med-INA.

Thrift, N. (2004). Intensities of feeling: towards a spatial politics of affect. Geografiska Annaler B, 86(1), 57-78. https://doi.org/10.1111/j.0435-3684.2004.00154.X

Thrift, N. (1996). Spatial Formations. Thousand Oaks, CA: Sage.

Torre, A., Aznar, O., Bonin, M., Caron, A., Chia, E., Galman, M., Guérin, M., Jeanneaux, P., Kirat, T., Paoli, J.-C., Salazar, M.I., Thinon, P. (2006). Conflits et tensions autour des usages de l'espace dans les territoires ruraux et périurbains. Le cas de six zones géographiques francaises (Conflicts and tensions over the use of space in rural and peri-urban landscapes: the case of six French geographical regions). Revue d'Économie Régionale \& Urbaine, 3, 411-450 (in French).

Van der Sluis, T. Pedroli, B. Kizos, T. (2014). Landscape change in Mediterranean farmlands: impacts of land abandonment on cultivation terraces in Portofino (Italy) and Lesvos (Greece), Journal of Landscape Ecology, 7(1), 23-44.

Vandecandelaere, E., Arfini, F., Belletti, G., Marescotti, A. (Eds.) (2009). Linking people, places and products. A guide for promoting quality linked to geographical origin and sustainable geographical indications, FAO-SINERGI, Rome. Retrieved from http://www.fao.org/docrep/013/i1760e/i1760e.pdf.

Woods M. (2005). Rural Geography: Processes, Responses and Experiences in Rural Restructuring, London: Sage Publications.

Wylie, J. (2007). Landscape. New York: Routledge.

Zapletal, M. (2012). Ecomuseum as a tool for preservation of traditional ecological knowledge and practices for sustainable development of landscape. In S. Lira, R. Amoeda, C. Pinheiro, P. Davis, M. Stefano, G. Corsane (Eds.) Ecomuseum 2012. Proceedings of the 1st International Conference on Ecomuseums, Community Museums and Living Communities (pp. 403-413). Green Lines Institute for Sustainable Development. Barcelos, 2012, Portugal.

Zizek, S. (2009) First As Tragedy, Then As Farce. London: Verso. 